\author{
Eusebius PRize Essay
}

\title{
The Politics of Sound and Song: Lectors and Cantors in Early Medieval Iberia
}

\author{
by MOLLY LESTER \\ United States Naval Academy \\ E-mail: mlester@usna.edu
}

In early medieval Iberia, Suevic and Visigothic conversions to Nicene Christianity in the 560 s and 580 generated ongoing episcopal and royal attention to cathedral liturgies and to the clerics who performed them. This article turns to this Iberian context to illuminate how lectors and cantors and their aural duties became increasingly central to the production of Christian orthodoxy. It is argued that in the early 6oos Visigothic anxieties over the production of correct liturgical sound eventually became a focal point of longstanding episcopal efforts to clericalise the minor officers of the Church.

$\mathrm{CCSL}=$ Corpus Christianorum Series Latina; $D E O=$ Isidore of Seville, De ecclesiasticis officiis; $D_{7} O E=$ De septem ordinibus ecclesiae, $\mathrm{MHS}=$ Monumenta hispaniae sacra; Toledo I etc $=$ First Council of Toledo

All citations of the canons of Tarragona, Toledo I and Toledo II are from La colección canónica hispana, IV: Concilios galos: concilios hispanos primera parte, ed. Gonzalo Martínez Díez and Félix Rodríguez, MHS, serie canónica, Madrid 1966. All citations of the canons of Toledo III and Toledo IV are from La colección canónica hispana, V: Concilios hispanos segunda parte, ed. Gonzalo Martínez Díez and Félix Rodríguez, MHS, serie canónica, Madrid 1992. All citations of the canons of Barcelona I, Braga I, Narbona and Mérida are from Concilios Visigóticos e Hispano-Romanos, ed. José Vives, Barcelona 1963.

A version of this research was presented at the Princeton University 'Bishops and Generals' workshop in April 2016, and I am grateful to the organisers for their invitation and to the participants for their feedback. I also benefitted from discussions with Rebecca Maloy, Emma Hornby, Kati Ihnat and Raquel Rojo Carrillo. Finally, I am especially grateful to Christopher Florio and to the anonymous reviewers for this JournaL for their suggestions. 
I

$\mathrm{n}$ the 610 Isidore of Seville instructed his brother Fulgentius, bishop of Écija, to curate the voices of clerics assigned to perform readings, chants and hymns in the Christian liturgy. In particular, readers (lectors) should have an 'unadorned and clear' voice, 'full of masculine vitality ... not too low nor extremely high, not sounding broken or immature, and not at all feminine'. The standards for singers (cantors or psalmists) were equally demanding, and their singing should not be 'harsh or raucous or dissonant, but melodious, pleasant, liquid, and sharp'. Such voices not only performed the liturgy: they also touched the souls of the Christian faithful. The lector 'ought to look after the ears and the heart' of a Christian congregant, and the psalmist's voice should 'create greater compunction' in hearers. ${ }^{1}$ For lectors and cantors, the quality of their voices was vital to the effective execution of their duty.

Aural duties were explicitly central to Isidore's conceptualisation of these clerical offices. Yet modern scholars have generally studied these subjects in isolation from one another. Church historians interested in ecclesiastical institutionalisation have studied the minor clerical orders within the context of the development of church offices, the ecclesiastical cursus and clerical duties. ${ }^{2}$ Musicologists and liturgists interested in the development of sacred sound and liturgical chant have prioritised how cantors and lectors were trained and educated, when and what they sang and read, and the standardisation and 'properisation' of readings and chant. 3

1 'Porro uox lectoris simplex erit et clara ... plena suco uirili ... non humilis nec adeo sublimis, non fracta uel tenera nihilque femineum sonans ... Auribus enim et cordi consulere debet lector': Isidore of Seville, $D E O$ II.xi.5 at p. 71 ; 'Vox autem eius non aspera uel rauca uel dissona, sed canora erit, suauis, liquida atque acuta ... quae conpunctionem magis audientibus faciat': II.xii.2 at pp. 71-2. All citations of this text are from Isidore of Seville, De ecclesiasticis officiis, ed. Christopher M. Lawson, CCSL, cxiii, Brepols 1989. Page numbers are provided directly after the relevant passage numbers.

${ }^{2}$ The major studies of the minor orders in the late antique Church remain J. G. Davies, 'Deacons, deaconesses, and the minor orders in the patristic period', this Journal xiv (1963), 1-16, and A. Faivre, Naissance d'une hiérarchie: les premières étapes $d u$ cursus clérical, Paris 1997. For the minor orders in Rome see Michel Andrieu, 'Les Ordres mineurs dans l'ancien rit romain', Revue des sciences religieuses v/ 2 (1925), 232-74, and Balthasar Fischer, 'Esquisse historique sur les ordres mineurs', Maison-Dieu lxi (1960), 58-69. For the development of ecclesiastical offices see James Burtchaell, From Synagogue to Church: public services and offices in the early Christian communities, Cambridge 1992; Hans von Campenhausen, Ecclesiastical authority and spiritual power in the Church of the first three centuries, trans. J. A. Basker, Stanford, CA 1969; Hermann Hauser, L'Église à l'âge apostolique: structure et évolution des ministères, Paris 1996; and Georg Schöllgen, Die Anfänge der Professionalisierung des Klerus und das kirchliche Amt in der syrischen Didaskalie, Münster 1998, 34-80.

3 For early medieval examples see Joseph Dyer, 'Boy singers of the Roman schola cantorum', in Susan Boynton and Eric Rice (eds), Young choristers, 650-I 7oo, Woodbridge 2009, 19-36, and James W. McKinnon, 'Lector chant versus schola chant: a question of historical plausibility', in Janka Szendrei and David Hiley (eds), Laborare fratres in unum: 
In this article, my aim is to join these subjects as I explore the institutionalisation of the offices of lector and cantor in relation to concurrent debates over sacred song and aural order. To do so, I will focus on early medieval Iberia, a region where royal and episcopal interest in orthodox Christianity as a means of political integration forced bishops to grapple with the varieties of Christianity across the peninsula. 4 In the sixth century, bishops of the Suevic kingdom of Gallaecia attended two councils in Braga in $5^{61}$ and 572 to reform Christian clergy and liturgy within the realm. Similar efforts took place on a larger scale within the Iberian Visigothic kingdom: after the conversion of the Visigothic king Reccared $\left(5^{87}\right)$ and the Visigothic people (589) from Arian to Nicene Christianity, bishops and rulers strove to cultivate Christian orthodoxy throughout the seventh-century kingdom. Central to all of these efforts was the problem of how to actualise correct faith through correct worship and moral habits. In the context of continuous reform and reflection, Iberian writers produced some of the most explicit literature on Christian practice and its orthodoxy of the late antique and early medieval period.

One key component of these urgent debates over orthodoxy was a deep interest in the performance of the cathedral liturgy. This interest not only generated special attention to the liturgy's aural components, but it also cast the responsibilities of cantors and lectors into sharp relief. Cantors and lectors and their performance were together deemed central to the larger performance of Christian orthodoxy, with the result that orthodox sound and song eventually permeated the conceptualisation and description of these offices. In order to make clear how Iberian authors increasingly embedded aural orthodoxy into their conceptualisation of these offices, I will begin by sketching the clericalisation of lectors and cantors in the late antique Church and outlining patristic debates over sacred sound. I will then examine these themes in early medieval Iberia, focusing in particular on the Iberian lectorate and on anxieties over liturgical music and reading. Finally, I will bring these themes together in an examination of Iberian conceptualisations of lectors and cantors as ecclesiastical officers whose most important duty was the production of orthodox Christian sound.

Festschrift László Dobszay zum 6o. Geburtstag, Hildesheim 1995, 201-10. For properisation see James McKinnon, The Advent project: the later seventh-century creation of the Roman mass proper, Berkeley, $\mathrm{CA}_{\mathrm{A}}$ 2000, and subsequent reviews.

${ }_{4}$ See, for example, L. Fernández Ortiz de Guinea, 'Participación episcopal en la articulación de la vida política hispano-visigoda', Studia Historica: Historia Antigua xii (1994), 159-68; R. Letinier, 'Le Rôle politique des conciles de l'Espagne wisigothique', Revue historique de droit francais et etranger lxxv (1997), 617-26; and Rachel Stocking, Bishops, councils, and consensus in the Visigothic kingdom, 589-633, Ann Arbor, Mi 2000. 


\section{The making of the minor orders}

How, when and why did cantors and lectors become salaried officers of ecclesiastical institutions? While it is tempting to assume that the earliest appearances of the terms lector and cantor refer to clerical offices, the local diversity of early Christianity as well as the honorary nature of many offices and titles in the Greco-Roman world make it difficult to determine whether such terms represent fully-fledged institutions. 5 Perhaps even more so than bishops, presbyters and deacons, the titles, hierarchies and duties of minor church officials varied dramatically across early churches. ${ }^{6}$ Christian doorkeepers, readers, exorcists and singers hovered in a liminal zone between clergy and laity, 7 and aside from basic literacy, there were no discernible limitations on who could read sacred texts or chant Psalms and hymns in early Christian gatherings. ${ }^{8}$

Nevertheless, scholarly consensus holds that between 200 and $25^{\circ}$ Christian authors began to use lector to indicate an official clerical position and to describe ordination rites for minor orders. 9 These lectors of the third century read Scriptures during Christian worship and possibly sang and chanted as well. The reasons for the institutionalisation of the lectorate at this historical moment are unclear, and scholars have variously attributed the phenomenon to the numerical increase of Christian congregations or to the increasing responsibilities of deacons. ${ }^{10}$ Nevertheless, lectors were still less privileged than higher grades such as presbyter and deacon, and, where present, ordination rites for all minor officers lacked an imposition of hands that imparted gifts of the Holy Spirit. ${ }^{11}$

After the legalisation of Christianity in the fourth century, the ongoing and dramatic increase of imperial bureaucracy and administration likely

5 For the historiography of Christian office see Conrad Leyser, 'Law, memory, and priestly office in Rome, c. 5oo', Early Medieval Europe xxvii/1 (2019), 61-84 at pp. $63-5$. For early Christian concepts of office see R. P. C. Hanson, 'Office and the concept of office in the Early Church', in his Studies in Christian late antiquity, Edinburgh 1985, $117-43$.

6 Davies, 'Deacons, deaconesses, and the minor orders', 10-11.

7 For analysis of this distinction see Faivre, Naissance.

8 Davies, 'Deacons, deaconesses, and the minor orders', 10; Harry Y. Gramble, Books and readers in the Early Church: a history of early Christian texts, New Haven 1995, 220. Jewish models are emphasised in Burtchaell, From Synagogue to Church, 258-62, and Faivre, Naissance, 58. Roman rhetorical and domestic readers are stressed in A. Quacquarelli, 'Alle origini del "lector", in Convivium Dominicum, Catania 1959, 381-406, and William Shiell, Reading acts: the lector and the early Christian audience, Leiden 2004.

9 Davies, 'Deacons, deaconesses, and the minor orders', $1_{5}$. For ordinations see Paul Bradshaw, Ordination rites of the ancient Churches of East and West, New York 1990.

${ }^{10}$ Davies, 'Deacons, deaconesses, and the minor orders', 4; Fischer, 'Esquisse historique', 60 .

${ }^{11}$ Faivre, Naissance, $5^{1-6 .}$ 
influenced Christian churches to hasten their own bureaucratisation. ${ }^{12}$ As bishops fought over the scope of their authority and definitions of Christian orthodoxy, they sought to increase their control over lower clerical orders. As a result, Christian elites increasingly insisted that lectors and other minor church officials were closer to the clergy than the laity. The lectors of the fourth century increasingly received salaries from their churches and underwent rites of ordination, and lectors were subject to stricter regulations on sexual activity and behaviour outside of church services. The composition of the lectorate shifted as well, and over the course of the fourth century, lectors were increasingly young boys and teenagers rather than adult men. ${ }^{13}$ Often these were children dedicated to serve the Church, and reading as lectors formed a central component of their education. Eventually, the lectorate came to be considered a starting place for advancement within the clerical cursus honorum, as the moral and grammatical education boys acquired as lectors would serve them when they become deacons, presbyters and perhaps even bishops. ${ }^{14}$ Many of these young men also presumably served as psalmists and cantors, offices that began to appear in Greek literature in the fourth century and in the Latin West in the fifth and that consistently ranked beneath lectors within the ecclesiastical hierarchy. ${ }^{15}$

Yet these trends were far from universal, and clerical office in the later Roman Empire was still in a state of 'flux'. ${ }^{16}$ The duties of lectors and cantors, for example, varied widely. Some communities indicated that lectors were responsible for reading Scripture aloud in Christian services, others awarded that duty to deacons, and others split the labour, with lectors reading the Old Testament and deacons reading the Gospels and Epistles. ${ }^{17}$ The question of singing (or modulated chanting) is even

${ }^{12}$ For the bureaucratisation of imperial government see A. H. M. Jones, The later Roman empire, 284-6о2: a social economic and administrative survey, Norman, Ок 1964, 366-410, 572-6o6. For imperial policy and ecclesiastical institutionalisation see Rita Lizzi Testa, 'Clerical hierarchy and imperial legislation in late antiquity: the reformed reformers', in Christopher M. Bellitto and Louis I. Hamilton (eds), Reforming the Church before modernity: patterns, problems, and approaches, Aldershot 2005, 87-103. Schöllgen argues that although the lifestyles of early Christian clerics and pagan priests often paralleled one another, there was no direct influence: Die Anfänge der Professionalisierung, 7-20, 31-3.

${ }^{13}$ John St H. Gibaut, The cursus honorum: a study of the origins of sequential ordination, New York 2000, 155; Gramble, Books and readers, 224.

${ }^{14}$ Gibaut, The cursus honorum, $5^{8-155}$.

15 Christopher Page, The Christian West and its singers: the first thousand years, New Haven 2010, 10-1, 99. For the monastic context see Margot Fassler, 'The office of the cantor in early western monastic rules and customaries: a preliminary investigation', Early Music History v (1985), 29-51.

${ }^{16}$ Leyser, 'Law, memory, and priestly office', 83 .

17 Davies, 'Deacons, deaconesses, and the minor orders', 13. 
more fraught: again, diversity was the rule rather than the exception, and depending on the community, deacons, lectors and eventually cantors sang in services.

Regardless of the competing and varied conceptions, as singers and readers became increasingly absorbed into the clerical hierarchy, clericalisation ironically cemented their low status: the 'institutionalisation and inferiorisation' of the minor orders went hand in hand. ${ }^{18}$ Minor officers remained poorly salaried and relatively marginal within the clerical community. ${ }^{19}$ Their sexual activity was increasingly subject to episcopal and presbyterial scrutiny, yet their behavioural standards remained laxer than those of the upper orders, and remarried men often lingered at the bottom of the clergy's moral hierarchy. While good singing could remain a source of prestige for deacons and for the bishops and rulers who employed them, ${ }^{2 \circ}$ the people who most often fulfilled this role remain largely invisible.

\section{Christian debates over senses}

At the same time that the offices of lector and cantor slowly solidified into 'starter' positions in the clerical hierarchy or terminal positions for men unable to meet higher moral standards, late antique Christian leaders voiced growing anxieties about the vocal performance and aural experience of the Christian mass. ${ }^{21}$ For Christian authors who inherited ancient sense theory, the human senses posed a particularly singular conundrum. ${ }^{22}$ Christians were often admonished to turn from the corporeal world towards spiritual things, and sensual pleasures could seduce Christians away from this high-minded goal. But theologians could not ignore the fact that the human body and soul depended upon sense perception, particularly after the Fall of Adam and Eve tied humans irrevocably to the material world and sinful flesh. ${ }^{23}$ Christian authors also struggled to articulate an idea of 'spiritual' senses, internal equivalents of

18 '[L]'institutionnalisation et l'infériorisation': Faivre, Naissance, 199.

${ }^{19}$ For salaries of minor officers see Page, The Christian West, 304, and A. H. M. Jones, 'Church finance in the fifth and sixth centuries', in P. A. Brunt (ed.), The Roman economy: studies in ancient economic and administrative history, Oxford 1974, 339-49 at p. 347 .

${ }^{20}$ Page, The Christian West, $212-14$.

${ }_{21}$ Carol Harrison, The art of listening in the early Church, Oxford 2013, 63-5.

${ }^{22}$ See Matthew R. Lootens, 'Augustine', in Paul L. Gavrilyuk and Sarah Coakley (eds), The spiritual senses: perceiving God in western Christianity, Cambridge 201 2, 56-70; Marcia L. Colish, The Stoic tradition from antiquity to the early Middle Ages, Leiden ${ }^{198} 5$, 170-1; and Michael Wagner, 'Sense experience and the active soul: some Plotinian and Augustinian themes', Journal of Neoplatonic Studies i/2 (1993), 37-62. For senses within cultural and historical epistemologies see Constance Classen, Worlds of sense: exploring the senses in history and across cultures, New York 1993.

${ }_{23}$ Harrison, The art of listening, 33-6, 74-6. 
the bodily senses that strove to perceive the non-physical divine as opposed to the physical world (the 'eye of the mind' or the 'ear of the heart'). ${ }^{24}$ Far from being taken for granted, human sensation and perception elicited ongoing philosophical and religious debate, yet consistently defied theorisation.

Despite a lack of consensus on the reliability of the human senses, ancient and early medieval authors generally agreed that the impressions perceived by the senses had a profound effect on the human mind. Sensual perceptions, they contended, were literally imprinted on the mind, a process that had the power to shape the mind: one of the most common ancient analogies for this process was the impression left by a seal in wax. ${ }^{25}$ One had to be very careful what sort of perceptions one exposed oneself to, so that the mind was kept pure and untainted rather than polluted by dangerous impressions of the world. ${ }^{26}$

Yet ordinary Christians did not live, and did not aspire to live, in a world of wilful sense deprivation. On the contrary, as Béatrice Caseau has argued, strict patristic admonitions to control the senses coincided with a rapid increase in evidence for the richness of sensory experiences in worship. ${ }^{27}$ Moreover, Christian worship interpreted as well as provided sensory experiences, and changes in liturgical ritual or church architecture reflected changing trends in how Christians (or Christian clerics) envisioned a person's access to the divine. These liturgical interpretations of sensual experience were far more commonly encountered by ordinary Christians than medical or theological theories, and just as ritual drew upon the senses, so it reciprocally constructed relationships between the body and the world that could carry beyond church walls. ${ }^{28}$

Increasing concern over proper sensual perception of liturgy amplified ongoing arguments over the place and merits of sound in Christian

${ }^{24}$ For the inner senses see Gavrilyuk and Coakley, The spiritual senses, and Simon Kemp and Garth J. O. Fletcher, 'The medieval theory of the inner senses', American Journal of Psychology cvi (1993), 559-76. For inner senses in devotional practices see Robert Deshman, 'Another look at the disappearing Christ: corporeal and spiritual vision in early medieval images', Art Bulletin lxxix (1997), 518-46.

${ }^{25}$ For example, Augustine, De trinitate 1 1.1.2-3. For the medieval mind as imprintable see Harrison, The art of listening, 61-83, and Mary Carruthers, The book of memory: a study of memory in medieval culture, 2nd edn, Cambridge 2008, 18-55.

${ }_{26}$ See Susan Ashbrook Harvey, Scenting salvation: ancient Christianity and the olfactory imagination, Berkeley, CA 2006.

${ }_{27}$ Béatrice Caseau, 'Christian bodies: the senses and early Byzantine Christianity', in Liz James (ed.), Desire and denial in Byzantium: papers from the thirty-first spring symposium of Byzantine studies, University of Sussex, Brighton, March 1997, Aldershot 1999, 101-9. Although her focus is eastern Christianity, contemporary western sources reflect similar patterns.

${ }_{28}$ Harvey, Scenting salvation, 4-5; Éric Palazzo, 'Art, liturgy, and the five senses in the early Middle Ages', Viator xli/1 (2010), $25^{-5} 5^{6}$ 
worship. ${ }^{29}$ In the context of doctrinal debates and the coalescence of a scriptural canon, one of the more obvious areas of concern was the content of readings, chants and hymns. But there was equal concern over how Scripture was read and music was performed in Christian worship. Late antique Christians had inherited classical education's emphasis on correct rhetoric and grammar, and many authors held that mispronounced or poorly read texts could have devastating consequences. $3^{\circ}$

Christians also argued about the benefits and drawbacks of music, particularly its mysterious ability to affect the human mood. Some Christian authors thought that music's affective qualities were unimportant, concerning or even misleading. Augustine, for example, worried that congregations would pay more attention to the music than to the holy words, and Ambrose was accused of leading his congregation astray with the charms of his hymns ('hymnorum carminibus'). ${ }^{31}$ Despite these reservations, other patristic authors argued that sacred song had extremely beneficial effects. One of the most commonly cited benefits was that music helped congregations more easily pay attention and remember what was sung in chants. ${ }^{22}$ Liturgical chant (along with scriptural readings) was also one of the primary ways in which the Christian laity heard and learned passages from the Bible, and song was a constant, consistent form of scriptural exegesis. 33 Pace changes, pauses and ascending or descending tones directed listeners' attention and highlighted certain words and concepts in the chant text. ${ }^{34}$ Rather than seducing Christians away from holy contemplation, music could impart the message of chants more deeply.

${ }^{29}$ See Music in early Christian literature, ed. James McKinnon, Cambridge 1987, and David Chidester, Word and light: seeing and hearing in religious discourse, Urbana, IL $1992,1-25$.

${ }_{30}^{\circ}$ For example, Irenaeus, Adversus haereses 3.7.2. See Gramble, Books and readers, 203-5, 218-31; Shiell, Reading acts, 126-7; and Page, The Christian West, 198.

$3^{1}$ Augustine, Confessions 10.33.49-50; Ambrose of Milan, Sermo contra Auxentium de basilicis tradendis 34 .

$3^{2}$ For example, Basil of Caeserea, Homilia in Psalmum 1 , and Nicetas of Remisiana, De utilitate hymnorum 5 .

33 For liturgical exegesis see Emma Hornby, Medieval liturgical chant and patristic exegesis: words and music in the second-mode tracts, Woodbridge 2009; Emma Hornby and Rebecca Maloy, Music and meaning in old Hispanic Lenten chants: psalmi, threni, and Easter vigil canticles, Woodbridge 2013; and William Flynn, Medieval music as medieval exegesis, Lanham, MD 1999.

34 For music and language see Ritva Jonsson and Leo Treitler, 'Medieval music and language: a reconsideration of the relationship', Studies in the History of Music i (1983), 1-23, and Edward Nowacki, 'Text declamation as a determinant of melodic form in the old Roman eighth-mode tracts', Early Music History vi (1986), 193-226. 
One of the best places to explore the confluence of aural orthodoxy and the officialisation of cantors and lectors is early medieval Iberia. Attending to the kingdom-wide liturgical reforms of the Suevic kingdom in the sixth century and the Visigothic kingdom in the seventh helps to illuminate changing conversations about the paradoxical discrepancies between the increasingly institutionalised lower status of lectors and cantors and the importance of their role in Christian services. The evidence also nuances the general narrative of the formation of the minor orders outlined above, as Iberian sources suggest that questions about lay or cler-

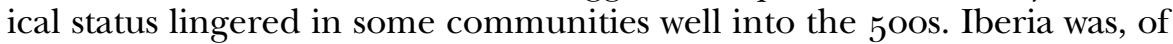
course, not the only Christian society that experienced such debates. But in the context of anxiety over orthodoxy, particularly orthodox liturgical practice, the conversations were louder and clearer here than in other early medieval communities.

Beginning in the fifth century, Iberian canons suggest that bishops struggled to determine where the minor orders lay on the spectrum between clergy and laity. 35 At the First Council of Toledo around 400, bishops from across the peninsula seem to have regarded the minor orders as an avenue for laypeople to join the clergy. They begrudgingly stated that lay penitents could be admitted to the clergy if some necessity compelled them to be recruited as doorkeepers or lectors. ${ }^{36}$ The bishops also decided that marriage did not necessarily bar a man from holding the office, declaring that if a lector took a widow as a wife, he would remain a lector or (if he was lucky) become a subdeacon; they also penalised widowed subdeacons who remarried with demotion to doorkeeper or lector. 37 The canons of Toledo I depict the minor orders as a space for laypeople who entered the clergy out of desire or need, or for clerics who failed to meet the higher moral standards required of deacons and presbyters. Nevertheless, the sinful condition of some lectors did limit the scope of their clerical activities. Penitent lectors and subdeacons demoted to lectors were barred from reading Epistle or Gospel passages during services..$^{8}$ The potential moral fallibilities of lectors, in conjunction with the recent Priscillianist controversy, might have also contributed to

35 For the education and expectations of the Iberian clergy see Justo Fernández Alonso, La cura pastoral en la España romanovisigoda, Rome 1955, 71-188, esp. pp. $99-101$.

36 'Item placuit ut de paenitente non admittatur ad clerum, nisi tantum, si necessitas aut usus exegerit, inter ostiarios deputetur uel inter lectores, ita ut euangelia et apostolum non legat': Toledo I, c. 2, in La colección canónica hispana, iv. 328-9.

37 Toledo I, cc. 3, 4 .

$3^{8}$ Toledo I, cc. 2,4 . 
the council's decision to ban lectors from visiting young virtuous girls in their homes. 39

The marital status, sexual behaviour and lay origins and appearance of the lectorate continued to concern Iberian bishops into the sixth century. At a provincial council in Tarragona in $5^{16}$, ten bishops declared that if lectors kept the company of adulterous women, they would be dismissed from the clergy..$^{\circ}$ The First Council of Braga in $5^{61}$ stated that laypeople could not be promoted to any priestly grade unless integrated first as a lector or subdeacon. ${ }^{4^{1}}$ Decades later at the Third Council of Toledo in 589 , in the context of the Visigothic conversion from Arian to Nicene Christianity, married Arian clerics who converted to Nicene Christianity and lived with their wives remained clerics, but were demoted to lectors. $4^{2}$ Proper clerical appearance was also a point of contention. The bishops at Braga I attempted to signal the lectorate's clerical status by forbidding lectors from wearing worldly clothing ('habitu saeculari') while singing or reading. 43 In $5^{89}$ a provincial council in Narbona reminded lectors that, like deacons and subdeacons, they were not to remove their albs until the mass concluded.44 Such debates persisted in the Visigothic kingdom, and in 633 the Fourth Council of Toledo reprimanded lectors of Gallaecia for improper tonsure and wearing their hair in the manner of laypeople and Arian heretics. 45

Although these councils met in different contexts, they all indicate that the norms established at Toledo I continued to influence decisions about the minor orders in Iberia. The ongoing efforts of bishops to establish norms for the lectorate suggest that the responsibilities and nature of the position remained nebulous in some regions well into the sixth century. Moreover, the evidence from Iberia suggests that scholars should be wary of embracing a neat narrative of increasing episcopal control over minor orders. Despite Matias Augé's claim that bishops generally ordained lectors, $4^{6}$ many churches in rural dioceses likely took matters into their own hands, and bishops were probably unable to supervise all the lectors in their see. A provincial council in Mérida in 666 acknowledged this reality by allowing presbyters to ordain minor clergymen in their parishes. 47 The canons also do not indicate when (or if) the lectorate of Iberia became a position overwhelmingly populated with young boys and

39 Toledo I, c. 6. See Virginia Burrus, The making of a heretic: gender, authority, and the Priscillianist controversy, Berkeley, CA 1995, 112.

$4^{1}$ Braga I, c. 20.

$4^{2}$ 'Si qui [converting Arian clerics] uero post hanc conuentionem obscene cum uxore elegerit uiuere, ut lector habeatur': Toledo III, c. 5, in La colección canónica hispana, v. $111 . \quad 43$ Braga I, c. 11.44 Narbona, c. 1245 Toledo IV, c. 41.

$4^{6}$ M. Augé, 'El sacramento del orden según los concilios españoles de los siglos IVvi', Claretianum v (1965), 71-93 at pp. 75-6.

47 Mérida, c. 18. See also Augé, 'El sacramento del orden', 77. 
teenagers dedicated to the Church. Like many areas of the Christian Mediterranean, there is evidence that young men could be lectors, as seen in an inscription from Mértola from $5^{66}$ that commemorated Tyberius, a fourteen-year-old 'lictor [lector]'.$^{8}$ Yet the fifth- and sixthcentury canons are ambiguous as to whether lectors were children, teenagers or adults. 49

Liturgical singers in Iberia are even more difficult to track. Unlike Rome and Gaul, there is no reliable evidence for deacons taking up singing duties, and Christopher Page has proposed that lectors initially carried out singing responsibilities. $5^{\circ}$ In Visigothic Iberia, idealised presentations of clerical hierarchies in pastoral and educational texts took the existence of cantors for granted. Outside of these texts, however, it is hard to find cantors in action. An inscription of about $5^{12}$, also from Mértola, commemorated 'Andreas ... princeps cantorum', $5^{1}$ but the phrase princeps cantorum is frustratingly vague, and there is no way to determine whether Andreas was a director or educator of singers or whether he was a lead singer himself. $5^{2}$ The anonymous Lives of the holy fathers of Mérida (c. 63os) stated that Fidel, a cleric (and eventual bishop) of Mérida, often sang in the cathedral choir, but did not name an office for Christian singers. 53 Finally, a sixth- or seventh-century inscription of a Psalm might have been part of a pedagogical exercise for clerics destined to sing it in services, 54 but the office of those clerics remains unknown.

Outside of sixth- and seventh-century evidence, some scholars argue that the emergence of Iberian cantors mirrored Roman and Frankish transitions from lector chant to schola chant. Famously defined by James McKinnon as a transition from soloists chanting Psalms to permanent, well-trained groups singing increasingly elaborate, standardised chants, many assume that this change occurred in seventh-century Iberia in concurrence with the development of increasingly complex Old Hispanic

$4^{8}$ Inscripciones cristianas de la España romana y visigoda, ed. José Vives, MHS, serie patristica II, Barcelona 1969, 34, no. 97.

49 The most-often cited evidence is Toledo II, c. 1 , which regulated the promotion of men dedicated to clerical office from infancy. Scholars have assumed that these men began their career as lectors: Augé, 'El sacramento del orden', 75; Faivre, Naissance, 274; Gibaut, The cursus honorum, $76-7$. Although they were indeed tonsured as children, the canon never identified them as lectors. The first office mentioned in their clerical cursus is the subdiaconate at the age of twenty-one.

$5^{\circ}$ Page, The Christian West, $210 . \quad 5^{1}$ Inscripciones cristianas, 33, no. $3^{2 .}$

$5^{2}$ Page, The Christian West, $216,234$.

53 Vitas sanctum patrum emeretensium 4.7: Vitas sanctorum patrum emeretensium, ed. A. Maya Sánchez, CCSL cxvi, Brepols 1992.

54 Las pizarras visigodas (Entre el latín y su disgregación: la lengua hablada en Hispania, siglos VI-VIII), ed. Isabel Velázquez Soriano, Burgos 2004, 194-5, no. 29. Strikingly, the inscription of the Psalm resembles a later version in an Old Hispanic psalter (p. 196). 
chants. 55 The evidence for this dating, however, is by no means conclusive. Visigothic Iberia certainly witnessed extensive liturgical innovation and composition that influenced later chants, yet projecting the contents of later manuscripts onto earlier centuries is fraught with methodological danger, and Rebecca Maloy's work on the flexibility and variability of chants indicates that Iberian liturgical music was in flux well past the seventh century. $5^{6}$ Although it is likely that cantors and groups of singers became more prevalent in the seventh century, it is difficult to determine when and how Toledo (much less other churches) possessed a schola cantorum along Roman lines.

\section{Aural order in the Iberian liturgy}

Beyond indicating the presence (or lack thereof) of cantors and lectors, the Iberian evidence also indicates a subtle shift in episcopal concerns over these minor church officers. While conciliar evidence from the fifth and sixth centuries primarily focused on lectors' and (wherever they existed) cantors' lay status, marital status and behaviour, the religious reform movements that convulsed the Suevic kingdom in the $5^{600}$ and especially the Visigothic kingdom from 589 onwards shone an increasingly harsh spotlight on the minor orders' liturgical duties. More and more, canons and texts anxiously discussed cantors and lectors not because of ill-behaviour or their potential proximity to laity, but because these minor officers were crucial architects of the aural order of the mass.

Until the late seventh century, it is unclear which readings and chants lectors and cantors were responsible for in the cathedral liturgy. In 400 Toledo I indicated that lectors normally performed the Epistle and Gospel readings (presumably in addition to Old Testament readings), and in 561 , at Braga I, lectors were presumably among the targets of a canon forbidding the reading of anything outside of the New and Old Testaments in mass. 57 Braga I also restricted lectors from handling liturgical plate and from distributing grains in the 'pagan rite' ('gentili riti'), $5^{8}$ suggesting that at least in Gallaecia, their responsibilities could extend beyond aural components. Pastoral descriptions of clerical hierarchies, such as those of Isidore of Seville, described different types of

55 McKinnon, 'Lector chant versus schola chant', 201 for Iberia; Don Michael Randel, 'Leander, Isidore and Gregory', Journal of Musicology xxxvi (2019), 498-522 at pp. 507-10.

$5^{6}$ Rebecca Maloy, 'Old Hispanic chant and the early history of plainsong', Journal of the American Musicological Society lxvii/ 1 (2014), 1-76, and 'Fixity, flexibility, and compositional process in Old Hispanic chant', Music and Letters xcvii (2016), 547-74.

57 Toledo I, c.2; Braga I, c.12. $5^{8}$ Braga I, cc, 10,1 1 . 
liturgical readings and chants, but were often content to state that reading generally belonged to lectors and singing to cantors.

The best witness to the specific duties of Iberian cantors and lectors is the late seventh- or early eighth-century pseudo-Isidorian Letter to Bishop Leudefredus. 59 In a detailed description of clerical offices and duties, the author wrote that 'to the psalmist belongs the duty of singing, to say blessings, psalms, Laudes chants, the responses of the sacrificia [offertory chants], and everything that relates to knowledge of singing'. ${ }^{60}$ The responsibilities of readers were more constrained. First, the author stated that readers were responsible for pronouncing 'readings' (lectiones) and 'those things which the prophets announced', the latter presumably meaning the Old Testament. ${ }^{61}$ In a following passage, however, they asserted that deacons were responsible for Epistle and Gospel readings, a relatively common practice in late antique Christian churches. ${ }^{62}$ Based on the discrepancy between the canons of Toledo I (c. 400) and this later text (c. 700 or later), lectors might have retained this responsibility for some time, but they seem to have lost this privilege by the eighth century.

Aural order in the liturgy also encompassed the manner and quality of delivery. To understand Iberian anxieties over the correct oral performance of the cathedral liturgy, ${ }^{63}$ one of the best places to start is Isidore of Seville, whose work reflected religious debates of the early 6oos and shaped future ones within the Visigothic kingdom. In the Etymologiae, a multi-volume encyclopaedia composed in the 620 s and 63os, Isidore underscored the importance of pace, inflection and emphasis for effective oration, and he emphasised music's abilities to aid memory, to persuade minds and to shape emotion. ${ }^{6} 4$ The interdependence between sound

59 For dating and authorship see Roger E. Reynolds, 'The "Isidorian" Epistula ad Leudefredum: an early medieval epitome of the clerical duties', in Roger E. Reynolds, Clerical orders in the early Middle Ages: duties and ordination, Aldershot 1999, III.

6o 'ad psalmistam pertinet officium canendi, dicere benedictiones, psalmos, laudes, sacrificii responsoria, et quidquid pertinent ad cantandi peritiam': Epistula ad Leudefredum 5, in The letters of Isidore of Seville, trans. Gordon B. Ford, 2nd edn, Amsterdam 1970 (using the Latin edition of $P L$ ), 10. For a later perspective see Don M. Randel, 'Responsorial psalmody in the Mozarabic rite', Etudes grégoriennes $\mathrm{x}$ (1969), 87-116.

61 'ad lectorem pertinet lectiones pronuntiare, et ea quae prophetae annuntiaverunt populis praedicare': Epistula ad Leudefredum 6, Letters of Isidore, 10.

62 Ibid. 11 . See also n. 17 above.

63 For the communicative potential of the liturgy see Eleonora Dell'Elicine, 'Discurso, gesto y comunicación en la liturgia visigoda $(589-711)$ ', Bulletin du Centre D'études Médiévales d'Auxerre, hors-série ii (2008), 1-23, <http://journals.openedition. org/cem/9862>.

${ }^{64}$ Isidore of Seville, Etymologiae II.i, xvi-xvii, xxi; III.xvi. See Etimologías: edición bilingüe, i, trans. José Oroz Reta and Manuel A. Marcos Casquero, Madrid 1982 (using the Latin 
and meaning also informed Isidore's ideas of liturgical reading and singing in an earlier pastoral work, De ecclesiasticis officiis (DEO). Originally titled De originis officiis, Isidore composed the text between 600 and $615 .{ }^{65}$ Although his primary purpose was to respond to his brother Fulgentius' request for an explanation of the origins of Christian worship, Isidore also seized the opportunity to reflect on contemporary Iberian liturgies and clerical offices.

One of music's most important aspects for Isidore was its effect on human emotion. According to Isidore, 'the custom of singing was instituted in the church not for the sake of the spiritual, but for the carnal, so that, because they are not pricked [to compunction] by the words, they might be stirred by the sweetness of modulation'. Christians who might not comprehend the words of Scripture and Psalms, or who might not be paying attention, might still be inspired and moved by whatever feeling the passages were meant to convey. Isidore also used Augustine's worried reflections on liturgical music in Confessiones, although he reorganised Augustine's words to convey affirmation rather than anxiety. ${ }^{66}$ When holy words are sung rather than said, 'our souls are moved more devoutly and ardently to the flame of piety'. Marvelling at the power of music, Isidore claimed that 'all our emotions are more excited through some mysterious kinship to the diversity or novelty of sounds when [something] is sung by an attractive and technically skilled voice'. ${ }^{67}$ Far from being mere window dressing to scriptural readings, the melodies of the mass were a 'gateway to Christian spirituality' that allowed all Christians, no matter how worldly or how simple, to draw nearer to fervent reverence of God and to recognise their own sins and repentance. ${ }^{68}$ Music allowed Christians to experience extreme joy, extreme sadness and a

edition of W. M. Lindsay). For Isidore on music see José J. A. Alfaro de Valle, 'Lo musical en San Isidoro de Sevilla [I]', and 'Lo musical en San Isidoro de Sevilla [II]', Revista del Instituto de Investigación Musicológica Carlos Vega ii (1978), 39-48; iii (1979), $55^{-78}$, and F. J. León Tello, 'La teoría de la música en las obras de San Isidoro', Música: revista trimestral de los conservatorios españoles i (1952), 11-28.

${ }_{65}$ See Lawson's introduction to De ecclesiasticis officiis, at pp. 13-15, 119-21.

66 Emma Hornby provides a detailed analysis of how Isidore repurposed this Augustinian passage: 'Musical values and practice in Old Hispanic chant', Journal of the American Musicological Society lxix/3 (2016), 595-650 at pp. 6oo-5.

${ }_{7}$ 'Propter carnales autem in ecclesia, non propter spiritales, consuetudo cantandi est instituta ut, quia verbis non conpunguntur, suauitate modulaminis moueantur ... Nam in ipsis sanctis dictis religiosius et ardentius mouentur animi nostri ad flammam pietatis cum cantatur quam si non cantetur. Omnes enim affectus nostri pro sonorum diuersitate uel nouitate nescio qua occulta familiaritate excitantur magis cum suaui et artificiosa uoce cantatur': Isidore, $D E O$ I.v.2 at p. 6 . For the third quotation I have used Hornby's translation in 'Musical values and practice', 600.

68 The quotation is from Hornby, 'Musical values and practice', 605. 
spectrum of emotions in between. It was a conduit to - and a concretisation of - religious experience.

Isidore also underscored how listening to a reading of Scripture could nourish the mind. Drawing on Nicetas of Remesiana's De utilitate hymnorum (c. $370-414)$, Isidore advised the congregant to listen diligently when a reading was performed 'lest with the pretext of prayer you lose the reading'. 'Nor', Isidore continued, 'should you think little usefulness proceeds from hearing the reading if in fact the prayer itself grows richer when the mind, fattened with a recent reading, runs through images of the divine things recently heard.' To ensure the desired impact of liturgical reading and music, Isidore repeated prior authors' admonitions that a service needed to be aurally organised. Twice in his discussion of liturgical readings, Isidore stated that "whether Psalms are being chanted or the reading is being recited, unity must be conserved by all, so that what is proclaimed to all might be heard equally by all'. ${ }^{69}$

Isidore's concern for music's ability to move souls was not merely an academic exercise. According to Emma Hornby, Isidore's musical values likely influenced melodic and repetitious strategies in notated Old Hispanic chant manuscripts. $7^{\circ}$ But attention to the aural shape of the liturgy existed before and during Isidore's own lifetime. Of the fifteen extant Iberian church councils of the sixth century, five contained one or more canons regulating liturgical chant. While some addressed the content of readings or the consistency of chants, other canons worried about how liturgical music was to be sung, particularly the order and the musical shape of chants. The bishops at the First Council of Barcelona in $54^{\circ}$ asked for a recitation of Psalm 1 before a 'canticle' (canticum), presumably referring to the practice of moving the position of Psalm 1 in the office of Matins depending on the day and liturgical season..$^{71}$ Perhaps the bishops reordered the chants in order to produce a desired effect in congregants depending on the liturgical season or to add an appropriate exegetical gloss on scriptural text. In 589 the Council of Narbona asked singers to break up long Psalms with pauses and to insert a repeated Gloria formula. $7^{2}$ This might seem to be micro-management on the part of bishops, but given the central role of music in congregational experience

\footnotetext{
69 'Nam et si tunc superueniat quisque cum lectio celebratur, adoret tantum deum et praesignata fronte aurem sollicite commodet ... obtentu orationis ne perdideris lectionem ... Nec putes paruam nasci utilitatem ex lectionis auditu'; 'siquidem oratio ipsa fitpinguior dum mens recenti lectione saginata per diuinarum rerum quas nuper audiuit imagines currit ... siue dum psallitur siue dum lectio pronuntiatur, ab omnibus unitas conseruetur, ut quod omnibus praedicatur aequaliter ab omnibus audiatur': Isidore, $D E O$ I.x.2-3 at p. 9 . $7^{\circ}$ Hornby, 'Musical values and practice'.

$7^{1}$ Barcelona I, c. 1. See Louis Brou, 'Notes de paléographie musicale mozarabe', Anuario Musicalv (1952), $5^{1-76}$ at p. 64. Many thanks to the anonymous reader who pointed out the connection to Matins.

72 Narbona, c. 2.
} 
and scriptural exegesis, even silent pauses could be pregnant with meaning.

Iberian reflection on the music and readings of the mass culminated in 633 at the Fourth Council of Toledo, presided over by none other than Isidore of Seville. The bishops at the council dedicated a large amount of attention to the question of liturgical singing, tackling the ordo, the content and the sequence of chants. Yet in these canons, we also catch a glimpse of pressing concern about liturgical music's ability to affect the mind and influence human emotion.73 For example, a decree against singing Alleluia in Lent had everything to do with cultivating the proper contemplative mindset for the season:

since this is not a time of joy, but of mourning, 'Alleluia' should not be sung. In this time there is need to pursue tears and fasts, to cover the body with sackcloth and ashes, to prostrate the soul with grief, to convert joy into sadness until the time of Christ's resurrection comes, when it is proper to sing 'Alleluia' in unrestrained happiness and to turn grief into joy. 74

Less explicit, yet equally intriguing, is canon 12 ordering that a 'Laudes' chant should be placed after the Gospel reading rather than after the Epistle. The thrust of this canon was that the Gospel should represent the culmination of the first half of the mass, and that Laudes was particularly appropriate to enhance this moment of praise and gratitude for the Word of God. Unfortunately, the canons of Toledo IV do not record the episcopal discussions behind their rulings, and we do not know what arguments about the affective qualities of music were brought up at this gathering. But the tenor of many Iberian canons from the $5^{\text {oos and early } 600 \mathrm{~s}}$ projects an acute awareness of the need for congruence between the emotional tone of the mass and sacred chants.

\section{The aural duties of cantors and lectors}

Episcopal attention to the aural organisation and experience of the liturgy increased episcopal scrutiny of the clerics who produced liturgical sound.

73 For premodern emotions see Barbara H. Rosenwein, Emotional communities in the early Middle Ages, Ithaca, NY 20o6, and Pierre-François Moreau, Bernard Besnier and Laurence Renault (eds), Les Passions antiques et médiévales, Paris 2015. For the modern invention of emotion see Thomas Dixon, From passions to emotions: the creation of a secular psychological category, Cambridge 2003.

74 "quia tempus est non gaudii sed maeroris, "Alleluia" non decantetur. Tunc enim opus est fletibus ac ieiuniis insistere, corpus cilicio et cinere induere, animum maeroribus deicere, gaudium in tristitiam uertere, quousque ueniat tempus resurrectionis Christi, quando oporteat "Alleluia" in laetitia canere et maerorem in gaudium commutare': Toledo IV, c. 11 , in La colección canónica hispana, v. 199. 
Lectors and cantors - teenagers, penitents, husbands - were assumed to hold the power to shape Christian hearts, minds and emotions. In contrast to many other late antique and early medieval regions, Iberian texts composed and circulating within the early and mid-seventh century stand out for their continuous recognition of the critical importance of lectors and cantors and their explicit links between the offices and aural orthodoxy. In particular, discussions of clerical hierarchy in two influential texts, the anonymous De septem ordinibus ecclesiae $\left(D_{7} O E\right)$ and Isidore's $D E O$, underscore lectors' and cantors' liturgical centrality.

De septem ordinibus ecclesiae, 'one of the first tracts in the western Church devoted to a formal consideration of the duties and hierarchical positions of the lower and higher ecclesiastical grades', offered a bold conceptualisation of the importance of the minor orders. 75 Although originally attributed to Jerome, the authorship, date and provenance of the text are indeterminate: the text was likely produced either in early fifth-century southern Gaul or in early seventh-century Iberia. $7^{6}$ Regardless of its origin, by the turn of the eighth century $D_{7} O E$ was popular in Visigothic Iberia, appearing frequently in Iberian canonical collections and manuscripts. 77 Many bishops knew the text well, and Isidore used it for his descriptions of clerical offices in $D E O$.

While the majority of $D_{7} O E$ offered an exhortation to embrace the duties and virtues of episcopal life, the text heavily promoted bishops' clerical inferiors and implored episcopal electees not to oppress the minor orders. When describing the office of the gravedigger, for example, the author instructed bishops 'not to think this office of gravediggers small', reminding them that lower priests were part of the bishop's household and liturgical services and comparing the ecclesiastical hierarchy to the human body: if a bishop was the head of a church, he still needed feet to walk. $7^{8}$ The text's subsequent discussion of lectors was no less emphatic. After declaring that God, Christ and the prophets had all given lectors the command to exalt their voices, the author ended by saying that 'their cadence is that of the angels ... [and they] are to some extent equal to you through this office of sanctity'.79 Regardless of provenance, $D_{7} O E$ 's circulation in the seventh-century Visigothic kingdom indicates that its message of the importance of the minor orders resonated with some episcopal reformers.

75 Roger E. Reynolds, 'The Pseudo-Hieronymian De septem ordinibus ecclesiae. notes on its origins, abridgements, and use in early medieval canonical collections', in Clerical orders, I, 238.

$7^{6}$ Ibid. I, $23^{8-40,252 .}$

77 Ibid. I, 240-4.

$7^{8}$ 'Non ergo putes paruum esse officium fossariorum': $D_{7} O E$, in Ps. Hieronymi de septem ordinibus ecclesiae, ed. P. Athanasius Walter Kalff, Würzburg 1935, 31, 34 .

79 'Horum numerus est angelorum et nomen angelus; qui usque adeo aequales tibi sunt per haec officia sanctitatis', ibid. 35 . 
Isidore of Seville would go further than the anonymous author of the $D_{7} O E$, uniquely combining his conceptualisation of these offices and his concerns for aural order. In the Etymologiae, Isidore centred his definitions of cantors and lectors on their effect on the Christian congregation. Psalmists 'sing to kindle the spirits of their audience to compunction', and lectors sometimes 'declaim in so heart-rending a way that they drive some people to sorrow and lamentation' ${ }^{80}$ Years earlier, in DEO, he had averred that those ordained as lectors be 'ornamented with knowledge of senses and words', ensuring that they would know 'where the sense [of a sentence] should hang to a greater degree' ${ }^{81}$ In these earlier statements, Isidore paraphrased works of the ancient grammarians Quintilianus and Varro, directly infusing the lectorate with Roman grammatical and rhetorical norms. Isidore also emphasised that the stakes of reading ambiguous passages with correct inflection and emphasis were extremely high, reminding readers that there are many things in Scripture which, unless they are pronounced in a proper manner, result in a contrary opinion' ${ }^{82}$ While he drew the sentiments of this quotation from Augustine, Isidore deliberately ensured that responsibility for orthodox interpretations of Scripture would fall on the lector's shoulders.

Isidore also cautioned that the tone and drama of a performance could have a strong impact on the listeners:

[The lector] will possess the power of delivery so that he may deeply move the minds and senses of all towards understanding, discerning styles of delivery and expressing the appropriate feeling of sentences, sometimes in a declaratory voice, sometimes sorrowful, sometimes rebuking, sometimes exhorting, or others similar to these according to particular types of pronouncement. ${ }^{83}$

8o '[Lectores] enim praedicant populis quid sequantur, [psalmistae] canunt ut excitent ad conpunctionem animos audientium; licet et quidam lectores ita miseranter pronuntiant, ut quosdam ad luctum lamentationemque conpellant': Isidore, Etymologiae vII. xii.24, in Etimologías: edición bilingüe, i. 68o, trans. Stephen A. Barney and others in The Etymologiae of Isidore of Seville, Cambridge 2006, 171.

81 'sensuumque ac uerborum scientia perornatus, ita ut in distinctionibus sententiarum intellegat ubi finiatur iuntura, ubi adhuc pendeat oratio, ubi sententia extrema claudatur': Isidore, $D E O$ II.xi.2 at p. 70. Quacquarelli argues for links between the importance of oral modulation for lectors and the oral practices of classical rhetors: 'Alle origini', $387-9,396-404$.

82 'Multa enim sunt in scripturis quae, nisi proprio modo pronuntientur, in contrariam recidunt sententiam': Isidore, $D E O$ II.xi.3 at p. 70 .

83 'Sicque expeditus, uim pronuntiationis tenebit ut ad intellectum mentes omnium sensusque permoueat, discernendo genera pronuntiationum atque exprimendo proprios sententiarum affectus, modo indicantis uoce, modo dolentis, modo increpantis, modo exortantis, siue his similia, secundum genera propriae pronuntationis': ibid. II. xi. 2 at p. 70. 
For psalmists (equated to cantors in $D E O$ II.xii.1), the tenor of the voice was also of paramount importance. To stir correct emotions and reactions in his listeners, a psalmist must 'be very clear and bright in voice and skill, so that he may stimulate the spirits of hearers by the pleasure of sweetness' ${ }^{8} 4$ Yet Isidore warned of the perils of over-emoting, and reminded psalmists that they should avoid styles reminiscent of classical theatre.

In these descriptions of the aural responsibilities of psalmists/cantors and lectors, Isidore was not introducing new material on the importance of correct liturgical sound. Drawing on Augustine, Ambrose, Nicetas and others, Isidore followed earlier patristic stances on the importance of proper melody and oration to incite proper emotions and understanding. But what was unique about Isidore's work was that he placed these aural responsibilities at the heart of his conceptualisation of these minor offices, a connection that prior texts on the ecclesiastical offices had either left implicit or failed to make. From the Apostolic constitutions to Ambrose's De officiis to the Statuta ecclesiae antiquae, no earlier description of lectors and cantors had placed such heavy responsibility for aural orthodoxy directly on the voices of these officials.

Given the immediate popularity of Isidore's texts in the Visigothic kingdom and their later prevalence in the Carolingian world, this conceptualisation found an eager audience, and Isidore's shift in emphasis resonated beyond his immediate context. Perhaps nowhere is this more explicit than in two prefatory poems to the tenth-century León Antiphoner, an Iberian monastic text containing chants for the masses and offices of an entire liturgical year. Both poems echoed the connections between music, the senses and emotions that are visible in the works of Isidore. While the first poem praised antiphons for 'warming the senses' ('sensus tu fobes') and easing hard hearts, the second ('Admonition to a Cantor') declared that cantors should sing with a 'contrite heart' ('corde contrito'). 'For whatever is meditated upon in the mind', advised the poet, 'the tongue expresses in the voice. ${ }^{.85}$

In the early Middle Ages, conversations about the minor church offices and liturgical sound were in no way confined to the Suevic and Visigothic king-

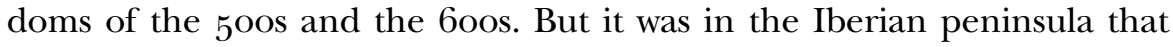
these conversations were the loudest, amplified by periodic religious reform movements coordinated between ecclesiastics, kings and state officials. In the quest for Christian orthodoxy, Iberian interest in correct

\footnotetext{
84 'uoce et arte praeclarum inlustremque esse oportet, ita ut oblectamento dulcedinis animos incitet auditorum': ibid. II.xii.2 at pp. 71-2.

85 'Quod ore depromes partier corde coniunge / meditetur mente quod lingua sonat voci': 'Admonitio cantoris': in Antifonario visigótico mozárabe de la Catedral de León, ed. Louis Brou and José Vives, Barcelona 1959, 6.
} 
liturgical practice exposed the complexities of the identities and duties of the minor orders of lectors and cantors. Church councils and pastoral texts record ongoing efforts to clericalise and regulate the minor orders, as lingering concerns over sexual behaviour, dress and relationship with other clerical grades persisted into the 6oos.

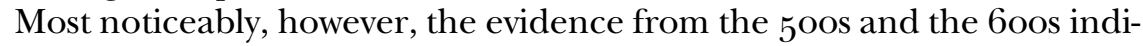
cates increasing acknowledgement that cantors and lectors were critical figures in actualising orthodox belief through orthodox practice in their performance in the liturgy. As a result, we witness an emphatic prioritisation of this in discussion of the minor offices. In Isidore of Seville's influential opinion, the orthodoxy of oral performance fused with the nature and duties of the offices: through care of a congregation's ears, lectors and cantors could directly minister to Christian hearts and minds. 